The sporidia of Chatomium murorum have a chink on one side, like those of the Spharia pedunculata, Dick., and S. hippotrichioides, Sow.

The true structure of Sphcronema is delineated in a species which grows upon the buds of Dahlias, which is almost identical with $S$. blepharistoma, figured in Mag. Bot. and Zool., vol. i.

The reproductive bodies of Tuber are beautifully figured, under Tuber fuscum. In the common truffle we find them just the same, and by no means such as represented by Turpin in his memoir on that genus.

The last illustration is perhaps the most important, being a complete confirmation of the views on the structure of hymenomycetous fungi, published in a late number of this journal*. It is most curious that Ascherson, Corda, Montague, Leveille, Brogniart and Decaisne should almost at the same time have observed the true structure of the hymenium in typical fungi.

It will not be thought invidious, if after calling attention to so many points of interest, (and there are many which we have not noticed,) we point out a few matters which might mislead. The author is certainly too hasty in the proposing new species and genera : indeed, many of his species appear to be the conidia of other fungi, or anomalous forms of described species. Bispora intermedia appears to be a correctly drawn Torula antennata. Halysium atrum is Spiloma melanopum, E. B. t. 2358 , which has been neglected by authors. Its nature is still doubtful. Periconia byssoides is either incorrectly drawn or is not the true plant of Nees, the flocci of which are articulated and the spores curiously granulated.

The species figured as Stilba appear to belong to other genera. Stilbum crystallinum is clearly Aspergillus albus, and Stilbum vulgare certainly not the true plant. Stilbum nodosum appears to be young Aspergillus maximus.

Other points might be noted, but we had rather again call the attention of our readers to the merits of the work, and recommend it very strongly to their patronage.

Commentationes de Leguminosarum Generibus. Auctore Georgio Bentham.

During an interesting and extensive tour lately made on the continent of Europe, our valued friend Mr. Bentham devoted his time, whether in the field or in the public and private museums, to the

* On the fructification of the Pileate and Clavate Tribes of Hymenomycetous Fungi, vol, i. p. 81. 
study of botany, with that energetic zeal which marks his character, and which induces him to labour, not for his own improvement only, but for the public good. One of the results of this tour has been the publication (at Vienna) of a 4to brochure, of 100 closely printed pages, under the title above given. Here are included a great number of most valuable observations on many new genera and species of Leguminosa, chiefly from the Herbaria of Munich and Vienna, where the collections were (as elsewhere) thrown open to him with a liberality which has called forth his grateful acknowledgements. His work, we are happy to learn from the preface, now that Mr. Bentham is returned to London, is but the forerunner of a more extensive one on this extensive family of plants.

\section{The Natural Arrangement and Relations of the Family of Fly-Catchers or Müscicapida. By William Swainson, Esq.*}

This work, one of the cheap and beautifully illustrated volumes of Sir William Jardine's Naturalist's Library, well sustains the character of that popular series. Mr. Swainson's talent as a zoological writer appears to be peculiarly fitted for works of this description,his slight sketches combine the beauty of a work of art, with the distinctness and accuracy so requisite in subjects connected with natural history. The text is an extension of the author's remarks on this family, originally published in the Ornithological volumes of Lardner's Encyclopædia, and contains much useful information, conveyed in an agreeable manner, and illustrated by thirty accurately coloured plates, beautifully engraved by Mr. Lizars. The work is published at such a moderate price as to place it within the reach of any person wishing to pursue the study of natural history, but who may hitherto have been prevented by the high price at which books on such subjects are usually brought out.

Much, however, as we are pleased with the general execution of this little volume, we cannot but regret that Mr. Swainson has not been more accurate in the orthography of the scientific names.

The same volume also contains an interesting memoir and plate of Baron Haller, the poet, the physiologist, and the naturalist.

\section{PROCEEDINGS OF LEARNED SOCIETIES.}

\section{GEOLOGICAL SOCIETY.}

April 4.-A paper was read, entitled, "A Description of Viscount Cole's specimen of Plesiosaurus macrocephalus (Conybeare)," by

* Jardine's Naturalist's Library : Lizars, Edinburgh ; Highley, London. 


\section{$2 \mathrm{BHL}$ Biodiversity Heritage Library}

1838. "Commentationes de Leguminosarum Generibus. Auctore Georgio Bentham." Annals of natural history 2, 63-64. https://doi.org/10.1080/00222933809496656.

View This Item Online: https://www.biodiversitylibrary.org/item/19464

DOI: https://doi.org/10.1080/00222933809496656

Permalink: https://www.biodiversitylibrary.org/partpdf/17321

\section{Holding Institution}

Natural History Museum Library, London

\section{Sponsored by}

Natural History Museum Library, London

\section{Copyright \& Reuse}

Copyright Status: NOT_IN_COPYRIGHT

This document was created from content at the Biodiversity Heritage Library, the world's largest open access digital library for biodiversity literature and archives. Visit BHL at https://www.biodiversitylibrary.org. 